\title{
Előretolt dallamesúcsok és emelkedő dallamok a magyar eldöntendő kérdések hanglejtésében ${ }^{1}$
}

\section{Bevezetés}

A kutatás tárgya a magyar eldöntendő kérdések intonációjának vizsgálata, ezen belül két aspektus tanulmányozása: (1) előretolható-e az utolsó előtti szótagról a dallamcsúcs ezekben a kérdésekben, illetve (2) milyen körülmények között kísérheti emelkedő végű dallam az eldöntendő kérdést.

Elsőként megmagyarázandó, hogy mit értünk a tanulmányban pontosan dallamcsúcson és emelkedő végü dallamon. Dallamcsúcsoknak az előző szótaghoz képest érzékelhető dallamemelkedést mutató szótagokat tekintünk: az általunk alkalmazott standardizációs eljárás alapján az előzőhöz képest legalább 10\%-os melodikus emelkedést mutató szótagokat, amelyek után a dallam ereszkedni kezd. Emelkedő végü dallamon pedig az egyirányú, egy bizonyos ponttól a megnyilatkozás végéig folyamatos emelkedést mutató dallamokat értjük, amelyekben az emelkedés nem torpan meg, és nem megy át szinttartóba.

A tanulmány során először áttekintjük az általános eldöntendő kérdések hanglejtésének főbb jellemzőit: a dallamváltozás irányát, kiindulási pontját, illetve a dallamcsúcsok lehetséges helyzetét. Összefoglaljuk, eddigi kutatások alapján mikor mutathat az eldöntendő kérdések dallama végső emelkedést a magyar nyelvben. Ezután ismertetjük egy percepciós kísérlet eredményeit: 30 magyar anyanyelvü felnőttel véleményeztettük 14 eldöntendő mondat hanglejtését, hogy megállapítsuk, az általános eldöntendő mondatokban a dallamcsúcs mennyivel tolható elörébb az alapértelmezett utolsó előtti szótagról, illetve teszteljük, természetesnek tartják-e és kérdésként értelmezik-e azokat a kérdő megnyilatkozásokat, amelyekben egy speciális lexikális elem jelenléte (pl. de, azért, ugye) mellett mondatvégi dallamemelkedés tapasztalható.

\subsection{Az általános eldöntendő kérdések intonációjának áttekintése}

A magyar közönséges eldöntendő kérdések intonációja alapértelmezetten nem emelkedő, hanem emelkedő-eső, hiszen, bár a mondat főhangsúlyos szótagjától emelkedés indul, ezt mindenképp esés követi az utolsó előtti szótagról. Vizsgálataink alapján (Baditzné Pálvölgyi 2012) az esés mértéke rendszerint meghaladja az azt megelőző legnagyobb emelkedés mértékét. Az alábbi ábra (1.) az emelkedés-esés lehetséges megvalósulásait szemlélteti: az emelkedés-esés a jelenlegi adataink alapján ötféleképp valósulhat meg:

1 A tanulmány az MTA Bolyai János kutatási ösztöndíj támogatásával készült. 


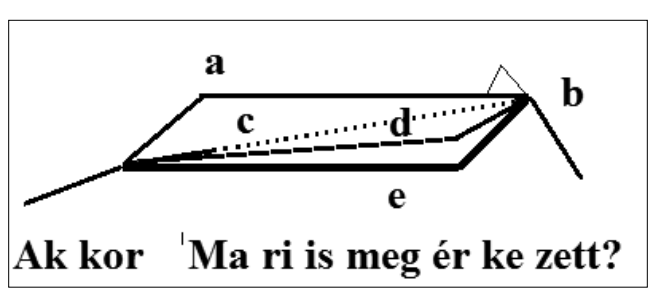

1. ábra. A magyar emelkedő-eső dallam variációi

a) az első hangsúlyos szótagig emelkedik, majd egy magas szinttartó plató után az utolsó előtti szótagtól esik;

b) az első hangsúlyos szótagig emelkedik, majd egy magas szinttartó plató után az utolsó előtti szótag előtt ismét emelkedik, majd az utolsó előtti szótagról esik;

c) az utolsó előtti szótagig emelkedik, majd onnan esik;

d) az utolsó előtti szótagig emelkedik, ott felugrik, majd esik;

e) az utolsó előtti szótagig alacsony szinttartó, majd emelkedik és esik.

Látható, hogy az öt variáns közös eleme az esés az utolsó elötti szótagtól kezdve; az előtte lévő részben mutatkoznak az eltérések. Idáig nem sikerült jelentésbeli különbségeket megállapítani az öt dallamvariáns között, de gyakoriságuk eltérő, legtöbbször a $d$ variáns mutatható ki, utána következik a $c$; az $a$, $b$ illetve $e$ variánsok igen ritkák. ${ }^{2}$

Fontos megemlíteni, hogy bár közös elemként az utolsó elötti szótag szerepel, mint a dallam legmagasabb pontja, elöfordulnak olyan - nem feltétlenül hibás mondatok is a vizsgálataink szerint, amelyekben a dallamcsúcs egy szótaggal elöretolódik, hátulról a második szótagra, és innen indul az esés (vö. még Markó 2007). Sőt léteznek olyan kérdő megnyilatkozások is, amelyekben a dallamcsúcs ennél is eggyel előrébb, hátulról a harmadik szótagra tolódik, ahogy saját korpuszom következő példája is szemlélteti:

A példa a BEA-adatbázisból (Gósy et al. 2012) származik, ${ }^{3}$ egy spontán társalgási szituációban elhangzó megnyilatkozás.

2 Varga (2002a) három lehetséges variánsról beszél, az $a, c$ és $e$ változatokról. A $b$ az $a$ és az $e$, a $d$ a $c$ és az $e$ hibridjeként értelmezhető abban a leírásban.

3 Saját korpuszom mondatait Cantero-Font-Rotchés (2020) módszerével standardizáltam, ezért a diagramon nem a Hz-ben megkapott értékek láthatók, hanem a standardizált görbe relatív értékei: minden egyes szótaghoz százalékban mérve megkapjuk a szótagok egymáshoz képesti dallamváltozását, majd ezeket a relatív értékeket egy önkéntesen 100-ról induló skálára relativizáljuk. A módszer az adatfelvételnél a dallamot a Praat-szoftver segítségével elemzi. Minden magánhangzónál a frekvencia középértékét veszi figyelembe, és a nagyobb inflexióknál (tonális elmozdulások) több érték is rendelhető egy magánhangzóhoz, amennyiben nincs tonális stabilitás a hangon belül, ilyen esetben az inflexió végpontjában mérjük az értéket A módszerről bővebben lásd Cantero 2002, 2005; Cantero-Font-Rotchés 2007, 2009; Font-Rotchés 2006, 2007, 2008, 2009. 


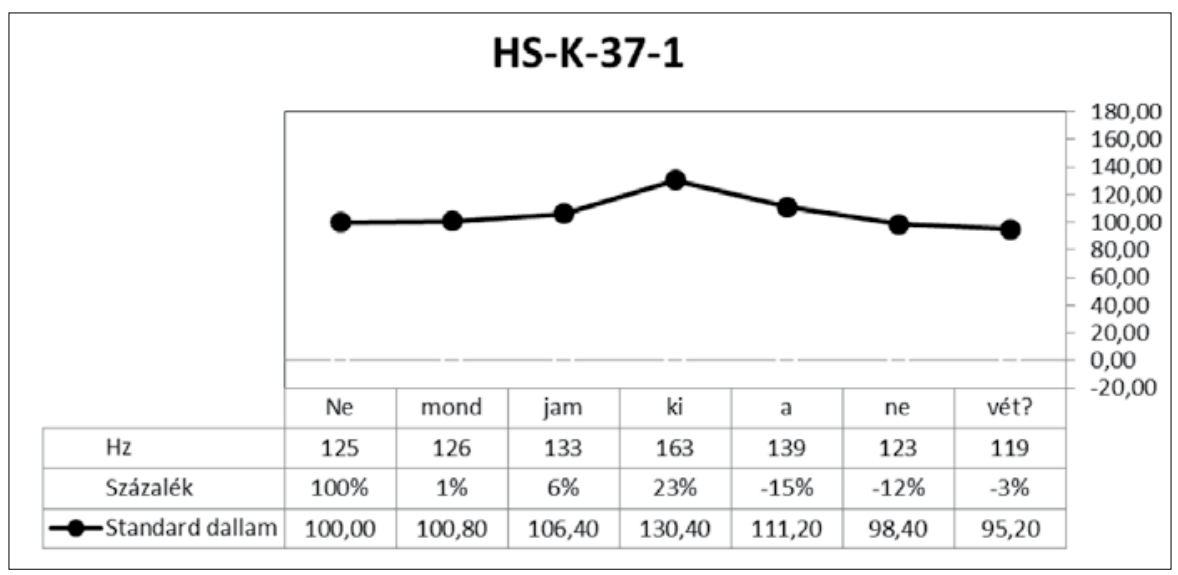

2. ábra. Olyan eldöntendő megnyilatkozás standardizált dallama, amelyben a dallamcsúcs hátulról a 3. szótagra tevődik át

\subsection{Emelkedő végü dallam az általános eldöntendő kérdésekben}

Az 1. ábrán felvázolt öt lehetőségen kívül bármely más intonációs megoldás, ${ }^{4}$ így az emelkedő végü dallam is lehetetlen a bemutatott példán, amennyiben általános (nem jelölt) eldöntendő kérdésről van szó:

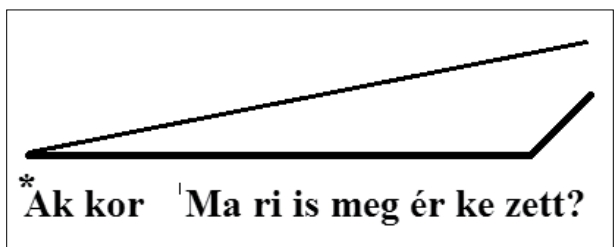

3. ábra. Az emelkedő végü dallam nem alkalmazható az általános eldöntendő kérdésekben (Az amerikai magyar emigránsok beszédében megfigyelhető az emelkedö dallamvég eldöntendő kérdésekben, az angol kérdő dallam interferenciájának eredményeként [Varga L., személyes közlés].)

Mindezek fényében kijelenthető, hogy a magyar általános eldöntendő kérdések esetén kizárólagosan az emelkedő-eső dallam kap szerepet. E dallam fonetikai megvalósulása azonban csonkulhat. Abban az esetben, ha a mondat rövid, maximálisan két szótagú, az emelkedő-eső dallamnak csak az emelkedő része valósul meg; az esés alig vagy egyáltalán nem (lásd 4. ábra). Az ilyen esetekben emelkedő dallamot találunk az általános eldöntendő kérdésekben, de itt csupán arról van szó, hogy az emelkedö-eső dallamot hordozó szakasz túlságosan rövid ahhoz, hogy egy komplex kontúr teljességében megvalósulhasson rajta, így fizikailag csupán egy emelkedő dallamot érzékelünk. Minimálisan három szótag szükséges ahhoz, hogy az esés is kötelezően megjelenjen.

4 Kivéve a már említett dallamcsúcs-előretolódást (lásd 2.1.). 


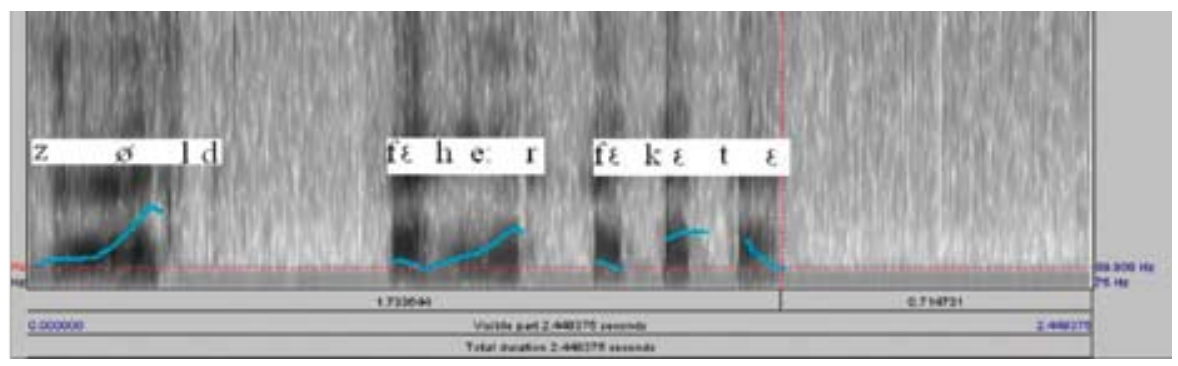

4. ábra. Az emelkedés-esés csak a három vagy több szótagos kérdésekben ábrázolódik (a példán a Zöld? Fehér? Fekete? kérdések dallama látható a Praat akusztikai szoftver ábrázolásában)

Tehát abban az esetben, ha legfeljebb két szótag hosszú eldöntendő kérdést teszünk fel, emelkedőként realizálódik a dallam vége; ez az emelkedés azonban egy fonológiailag emelkedő-eső dallam fonetikai realizációja, amely a dallamot „,csökevényesen" jeleníti meg (vö. Varga 2002b).

\subsection{Emelkedő dallam az emfatikus eldöntendő kérdésekben}

Ha a kérdés emfatikus - hitetlenkedő, kétkedő, és a beszélő azért teszi fel, hogy a partnere valami hihetetlen vagy nehezen érthető mondatot megismételjen vagy megmagyarázzon -, még akár az egy szótagos kérdésen is megjelenhet az emelkedés utáni esés, mint például (vö. 5. ábra):
A: $-E z$ kék.
B. - Kék??

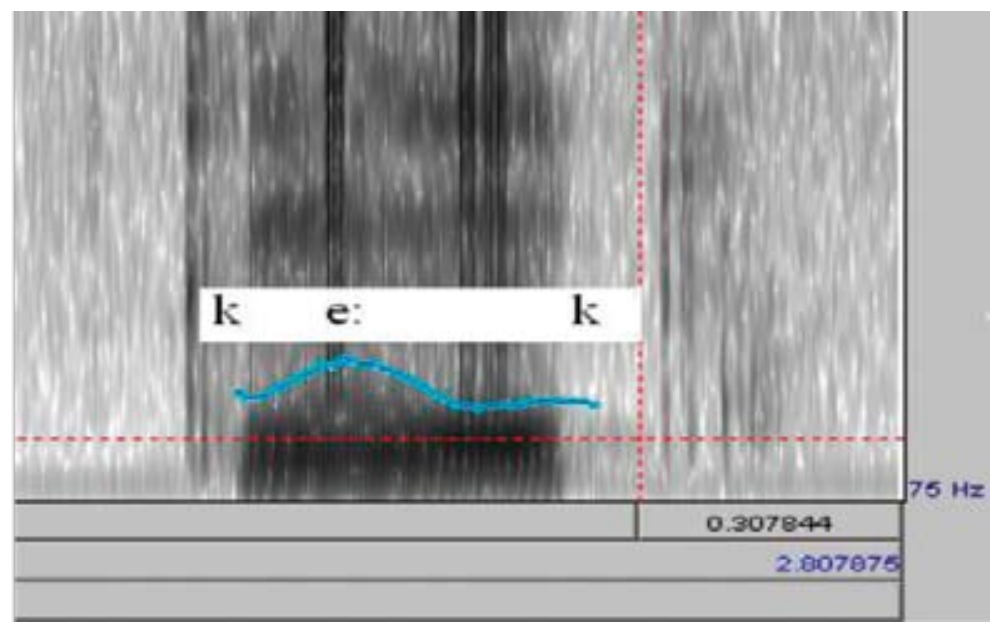

5. ábra. Emelkedés-esés már egy szótagnál is megjelenik az emfatikus kérdésekben 
Ezért úgy kell módosítanunk a 2.2.-ben mondottakat, hogy a maximálisan két szótagú, nem emfatikus eldöntendő kérdések intonációja lehet fonetikailag emelkedő.

A hosszabb emfatikus kérdésekben elöfordul, hogy a mondatban több föhangsúly van, és a mondat utolsó szavára is főhangsúly kerül. Ebben az esetben az emelkedőeső dallam, amely mindig a főhangsúlyról indul, a mondat utolsó szavára terjed ki. Ha ez a szó egy- vagy két szótagos, megint emelkedés figyelhető meg az eldöntendő kérdésben, hiszen az esés három szótagnál rövidebb hangsoron nem jelentkezik. A 6. ábra bal oldali példájában egyetlen főhangsúly van, az iz- szótagon, és ez emelkedő-eső dallamot indít. A jobb oldali példában a tej szótag is főhangsúlyos, ezért ezen nem tud megjelenni az emelkedő-eső dallam, csak annak emelkedő része.

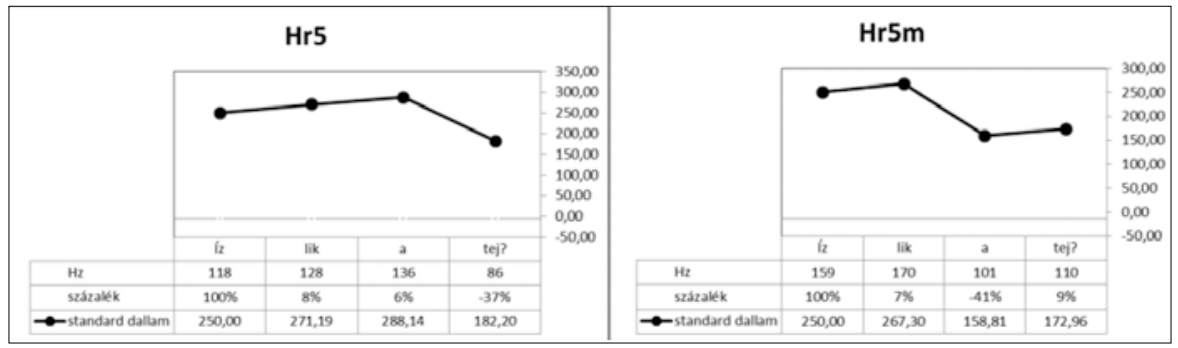

6. ábra. Az esés nem érzékelhető, ha föhangsúly van a mondat utolsó, legfeljebb két szótagú elemén

Láthattuk, hogy általános eldöntendő kérdésekben csak akkor lehet végén emelkedő dallam, ha:

- maximálisan két szótagosak, de nem emfatikusak (hitetlenkedő jelentéstartalommal);

- a mondat utolsó, maximálisan két szótagú elemén főhangsúly jelenik meg, és onnan indítja a dallamot.

Mindkét esetben azonban csak az emelkedő-eső dallam csökevényesen megvalósuló variánsáról beszélhetünk. Ami az ekkor bekövetkező emelkedés mértékét illeti, a megfigyelések alapján (Baditzné Pálvölgyi 2012) viszonylag alacsony értékről van szó, $40 \%$ alatti, de jellemzően kevesebb, mint 20\%-os értékkel.

\section{Az eldöntendő kérdések intonációja bizonyos lexikai elemek jelenlétében}

\subsection{Bizonyos lexikai elemmel jelzett eldöntendő kérdések intonációja}

Térjünk most át azokra az eldöntendő kérdésekre, amelyek kérdő jellegét valamilyen lexikai elem mutatja. Ezekben az emelkedő-eső kontúrt más dallam helyettesítheti. Ide tartoznak az olyan partikulák, amelyek csak kérdésekben használatosak, és az olyan 
szókapcsolatok is, amelyek nem csak kérdésekben szerepelhetnek, de amennyiben egy eldöntendő kérdésben jelennek meg, társíthatnak ahhoz egy speciális jelentéssel bíró, nem emelkedő-eső intonációs kontúrt is.

Lássuk tehát, mely lexikai elemek társaságában kísérheti végén emelkedő intonáció a magyar eldöntendö kérdést. A magyar nyelvben két partikula létezik annak jelzésére, hogy kérdésröl van szó. Az egyik a vajon, a másik az -e. Ezek közül a vajon kiegészítendő kérdésekben is, az -e csak eldöntendő kérdésekben használatos. A vajon esetében, ha eldöntendő kérdésben szerepel, a dallam a tipikus emelkedő-eső (7. ábra).

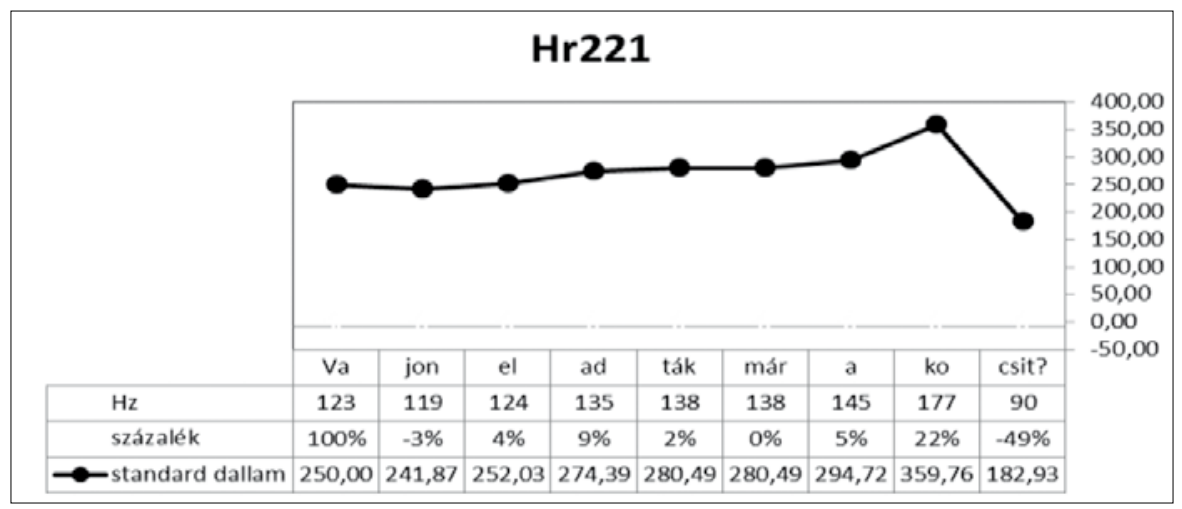

7. ábra. A vajon kérdőszó mellett az intonáció emelkedő-eső

Az -e szócska esetében a kérdés intonációja nem tükrözi az eldöntendő kérdések tipikus emelkedő-eső kontúrját, hanem a kijelentő mondatokra jellemző eső dallamot használja: ${ }^{5}$ a föhangsúlyos szótagról esik a dallam egy nagyobbat (15-30\% közötti értékben), és utána szinttartó vagy enyhén ereszkedő (lásd 8 . ábra).

Ha a két szócska, a vajon és az -e kombinálódik egy mondatban, az -e-re jellemző intonációs séma érvényesül, vagyis a mondat eső kontúrral áll (9. ábra).

5 Sürgető, számonkérő felhanggal az -e kérdőszavas eldöntendő kérdések állhatnak esőemelkedő dallammal is, ahol az emelkedés csak az utolsó szótagot érinti: Igaz-e?? Ezen kívül, mint minden mondattípusban, ahol alkalmazható az eső dallam, létezik még egy emfatikus, „eső zárású” változat is, amely emlékeztethet az emelkedő-eső dallamokra. Formailag az utolsó előtti szótag kis mértékủ megemelkedése jellemzi, ahonnan tovább esik a dallam. Ezt a változatot Egressy Gábor óta ,a kedély magyar akcentusa”-ként tarthatjuk számon, lásd Csüry $(1925,1928)$ és Varga (2009: 43-4). A következő példa is emfatikus, sürgetést, türelmetlenséget fejez ki: Na, készen van-e már a házi feladat? (az utolsó előtti szótagot kissé megemelve tovább esik az amúgy szinttartó vagy eső dallam). 


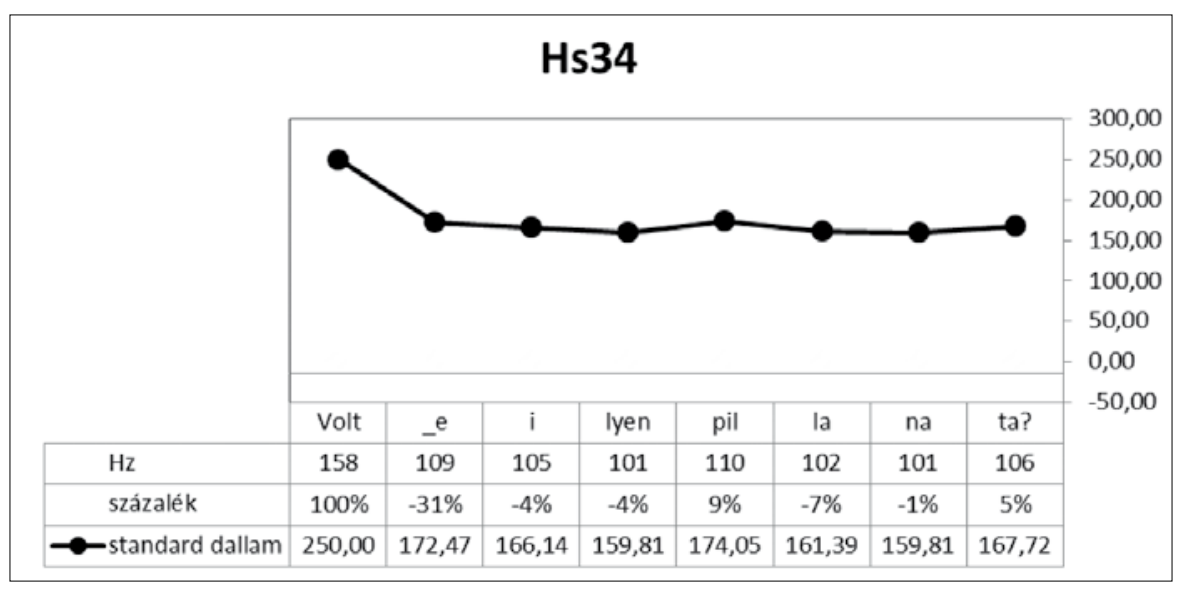

8. ábra. Az -e partikulával jelzett eldöntendő kérdések intonációja alapesetben eső

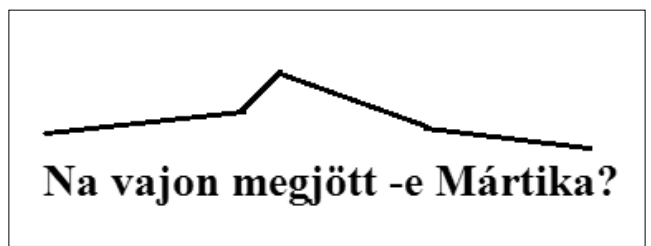

9. ábra. A vajon és az -e szócska kombinációjakor az eldöntendő kérdés intonációja eső

\subsection{Mondat végi emelkedő intonáció a speciális lexikális elemekkel ellátott eldöntendő kérdésekben}

Vannak olyan lexikális elemek, amelyek vajon és az -e elemmel ellentétben nemcsak az eldöntendö kérdésekben szerepelhetnek, hanem kijelentő mondatokban is. Amennyiben azonban eldöntendő kérdésekben szerepelnek, megváltoztathatják annak emelkedő-eső intonációját, és egy eső-emelkedő dallamot adhatnak nekik. Ezeknek a mondatoknak a felhangja meglepett, reménykedő vagy enyhén fenyegető, már-már felszólító jellegü is lehet. Jellemzően egy tagadószót és/vagy egy ellentétes értelmü kötöszót tartalmaznak, például: de ...(nem)..., de (azért)..., csak nem...

Azokban a mondatokban, amelyek tartalmazzák a nem szót, a szó viszonylag nagyobb emelkedést mutat az előző szótaghoz képest (10. ábra), mivel előtte hangsúlytalan szótagok állnak. Ez az emelkedés 10\% fölötti, de esetenként akár a 100\%-ot is elérheti, ha a mondat meglepetést tükröz (11. ábra). Minden megoldás esetén jellemző, hogy a föhangsúlyos szótagról süllyedés indul a dallamban, amely az utolsó elötti szótagig tart. Innen egy kisebbfajta emelkedés érzékelhető, 30\% alatt. 


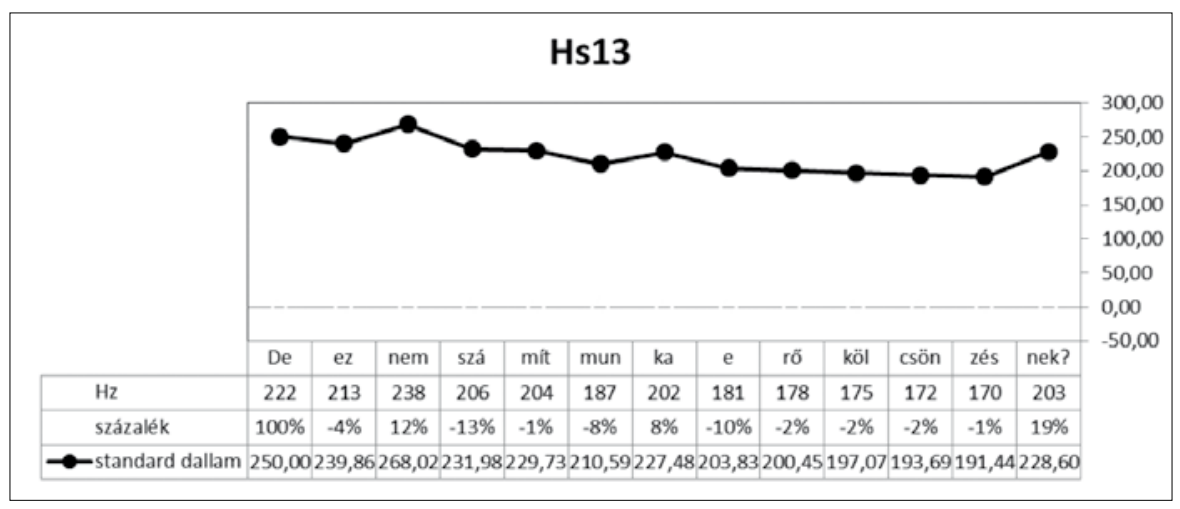

10. ábra. A meglepett beszélő speciális lexikai elemet tartalmazó eldöntendő kérdése eső-emelkedő

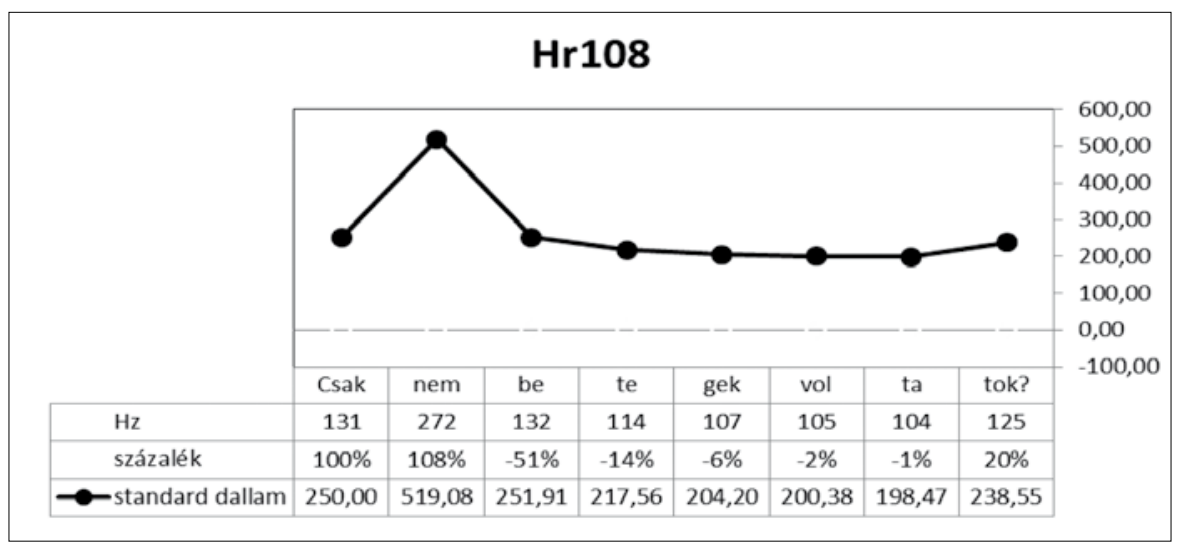

11. ábra. Az erősen meglepett beszélő lexikai elemmel is jelzett eldöntendő kérdése eső-emelkedő, a tagadószó nagyon magas

Két intonációs megoldás lehetséges azokban a kérdésekben, amelyek az említett elemeket tartalmazzák: a semleges eldöntendő kérdéseknél az emelkedő-eső, míg a reménykedő/fenyegető felhangú variánsoknál az eső-emelkedő dallam használatos (12. ábra).

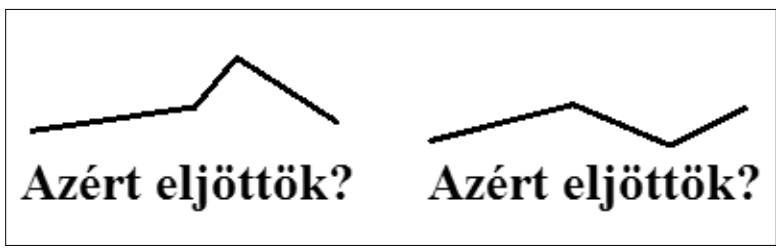

12. ábra. Az ellentétes kötőszót tartalmazó eldöntendő kérdéseknek kétféle intonációja lehet: emelkedő-eső (semleges) és eső-emelkedő (reménykedő, fenyegető) 
A csak nem szókapcsolat speciális, mivel ez esetben nem fordulhat elö egy semleges, emelkedő-eső intonáció is a mondatban (lásd 13. ábra):

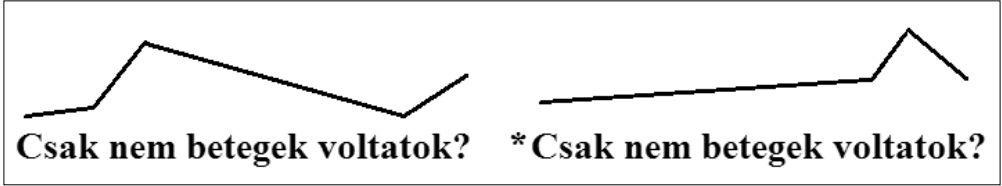

13. ábra. A csak nem szókapcsolatot tartalmazó eldöntendő kérdéseknek csak eső-emelkedő dallamuk lehet, emelkedő-eső nem

Az eső-emelkedő dallam ezen partikulák nélkül nem szokványos (14. ábra):

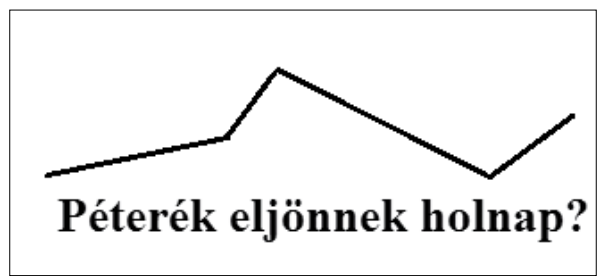

14. ábra. Az eső-emelkedő dallam csak bizonyos partikulákat kísérve fordul elö jellemzően

\subsection{Az eldöntendő kérdést jelző lexikai elemek intonációja az ugye szócska jelenlétében}

Az említett, eső-emelkedő intonációs kontúrt vonzó szókapcsolatok nem kombinálódhatnak jellemzően olyan szavakkal, amelyek eleve jelzik az eldöntendő kérdést, például De azért elment-e sétálni?, vagy Vajon csak nem megérkezett már?. Kombinálódhatnak azonban a zömében eldöntendő kérdésekben álló ugye szócskával, kivéve a csak nem... szókapcsolatot: Ugye csak nem beteg? ${ }^{6}$ Ezért először azt kell megvizsgálni, mi történik, ha egy eldöntendő kérdésben önmagában az ugye szerepel.

Ilyen esetben kétféle dallamot kaphatunk: ha a mondat végén szerepel az ugye, akkor egy önálló, az eldöntendő kérdésre jellemző emelkedö-eső dallamot kap ${ }^{7}(15$. ábra). Ha azonban nem az utolsó helyen szerepel a mondatban, az intonáció nem lehet emelkedő-eső, csakis a kijelentő mondatokéra jellemző eső dallam. Ez a dallam a főhangsúlyos szótagról esik viszonylag nagyobb értékben, bár a megfigyelések alapján a legjellemzőbb dallamesés a főhangsúly utáni második és harmadik szótag

${ }_{6}$ Bár az ugye jellemzően eldöntendő kérdésben szereplő partikula, nagy ritkán előfordulhat kijelentésekben is („Akkor ugye[bár] hiába mentem, mert nem volt otthon...”). Általában a tapasztalatok summázásakor, történetmesélés esetén szerepel kijelentő mondatokban.

7 Jobban látható az emelkedő-eső dallam, ha az ugye egy három szótagos, kissé elavult változatát, az ugyebárt használjuk. 
között is bekövetkezhet (lásd 16. ábra). Az esés mértéke általában 15-30\% közötti, ezt az értéket ritkán haladja meg.

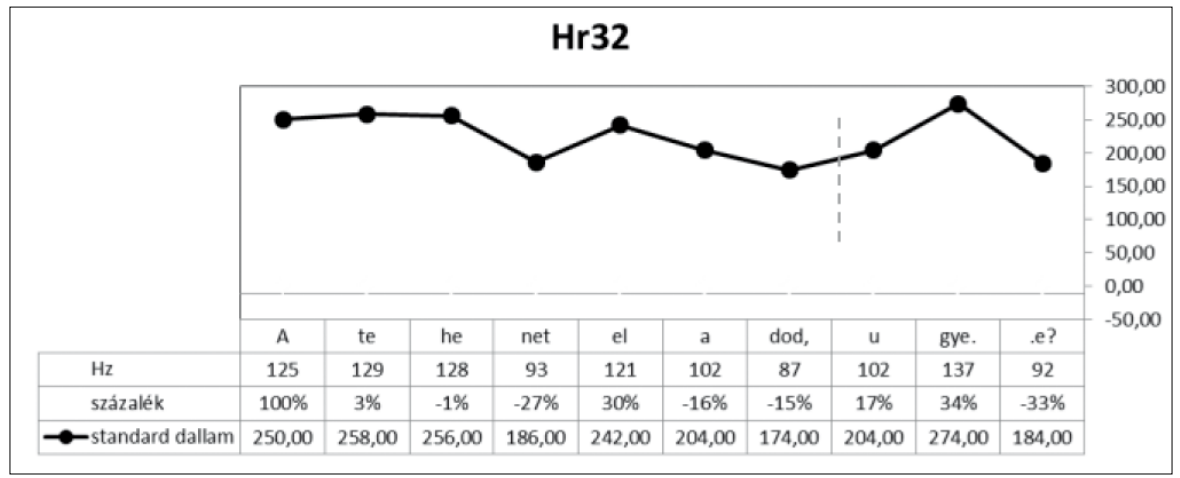

15. ábra. A mondatvégi ugye esetében az ugye külön emelkedö-eső kontúrt kap

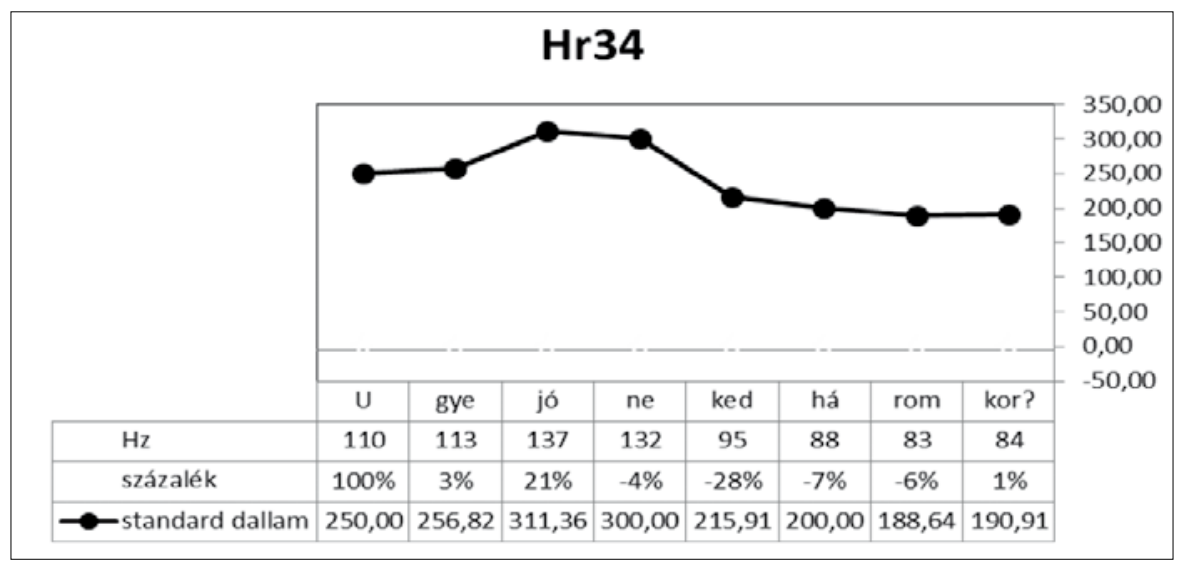

16. ábra. A mondatközben szereplő ugye esetén alapesetben az intonáció eső

Ha az eső-emelkedő kontúrt vonzó lexikai elemek (3.2.) az ugye szócskával kombinálódnak, az ugyé-s mondatokra jellemző eső intonációs kontúron kívül az esőemelkedő dallam is megjelenhet (17. ábra), reménykedő, fenyegető felhanggal.
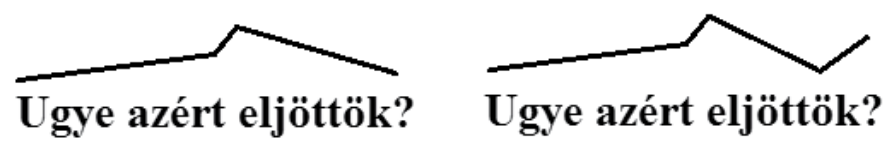

17. ábra. Az ugye szócskát is tartalmazó ellentétes kötőszavas eldöntendő kérdéseknek kétféle intonációja lehet: eső (semleges) és eső-emelkedő (reménykedő, fenyegető) 


\section{4. Összefoglalás: mely speciális lexikai elemek jelenléte okozhat végén emelkedő intonációt a magyar eldöntendő kérdésekben?}

A könnyebb áttekintés érdekében a következő táblázat összefoglalja, mely eldöntendő kérdésekben (is) alkalmazható speciális lexikai elemek milyen dallamot vonzanak.

1. táblázat. Eldöntendő kérdésekben szereplő speciális lexikai elemek és a megnyilatkozások dallama

\begin{tabular}{|c|c|c|}
\hline Partikulatípusok & Partikulák & Vele járó dallam \\
\hline \multirow{3}{*}{$\begin{array}{l}\text { Csak kérdésben alkalmazott } \\
\text { lexikai elemek }\end{array}$} & vajon & emelkedő-eső \\
\hline & $-e$ & eső \\
\hline & vajon $+-\mathrm{e}$ & eső / emelkedő-esö / eső-emelkedő \\
\hline \multirow{6}{*}{$\begin{array}{l}\text { Kérdésekben is alkalmazható } \\
\text { lexikai elemek }\end{array}$} & ugye & esö / emelkedő-eső / eső-emelkedő \\
\hline & de & emelkedő-eső / eső-emelkedő \\
\hline & azért & emelkedő-eső / eső-emelkedő \\
\hline & de + azért & emelkedő-eső / eső-emelkedő \\
\hline & de $\left\{\begin{array}{l}\text { ugye } \\
\text { ugye azért } \\
\text { azért ugye }\end{array}\right.$ & eső / eső-emelkedő \\
\hline & csak nem & eső-emelkedő \\
\hline
\end{tabular}

Látható tehát, hogy a fonológiailag is emelkedő végủ dallamok a magyar eldöntendő kérdések olyan változataiban szerepelnek, amelyek tartalmazzák a következö elemeket: de, ugye, azért (ezek szabadon kombinálhatók, akár mindhárom szerepelhet egymás után bennük) és a csak nem. Ez utóbbi esetben az eldöntendő kérdést kizárólagosan kíséri az eső-emelkedő dallam, míg a többi esetben csak az egyik - hol finoman fenyegetö, hol reménykedő - felhangú változatot jellemzi.

A következőkben rátérek a percepciós teszt ismertetésére, amelynek segítségével azt vizsgálom többek között, hogy a de azért, ugye és vajon elemeket tartalmazó eldöntendő kérdések esetében mennyire tekinthető természetesnek a megnyilatkozásban alkalmazott emelkedő végü dallam.

A kutatási kérdések a következők:

(1) Az általános eldöntendő kérdésekben hány szótaggal tolható elöre az alapértelmezetten az utolsó előtti szótagon álló dallamcsúcs?

(2) Bizonyos partikulák esetén (de, azért, ugye, vajon) mennyire tartják természetesnek a beszélők az emelkedő végü dallamot? 


\section{Módszertan}

A vizsgálatot mondatpárokkal, illetve mondatcsoportokkal rögzítettem, amelyek egyik tagját egyszer vettem fel ugyanazzal a beszélővel, és a többi tagját pedig a Praat (Boersma-Weenink 2020) szerkesztő felületén manipuláltam, tehát egy ponton megváltoztattam a dallamát. A következő ábra azt szemlélteti, hogyan változtatható a programban a megnyilatkozás dallama mesterségesen:

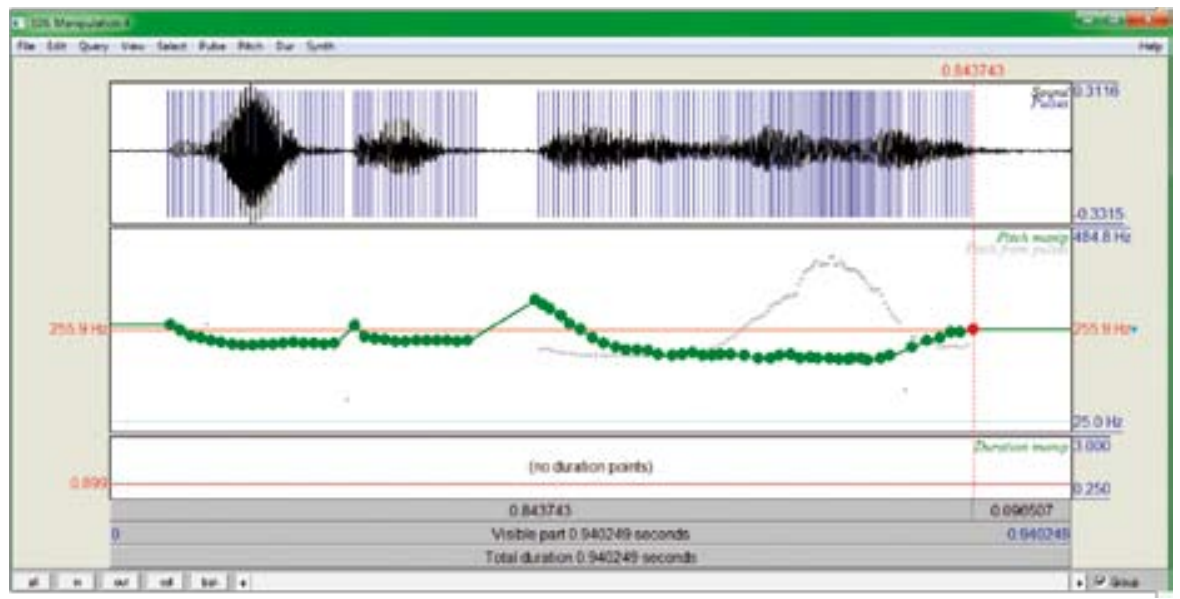

18. ábra. Mesterséges dallammanipuláció a Praat-programban

Az ábrán az látható, az eredetileg emelkedő-eső dallam helyett egy eső-emelkedőt kapunk a megnyilatkozásban. Az így szintetizált dallam beszélője, időtartama, intenzitásértékei megegyeznek az eredetivel, az egyedüli különbség a dallam. A manipulációra azért volt szükség, hogy ugyanazt a beszélőt hallva egyetlen változó (a dallam) esetén objektíven lehessen vizsgálni, hogyan érzékelhető a különbség.

A következő mondatokat hallották a kitöltők: És Péterék eljönnek vasárnap? (Háromszor, minden alkalommal emelkedő-eső dallammal, először utolsó előtti szótagos dallamcsúccsal, majd egy-egy szótaggal elörébb tolva a dallamcsúcsot). Meglepte a kép? (Négyszer, minden esetben emelkedő-eső dallammal, először utolsó előtti szótagos dallamcsúccsal, majd egy-egy szótaggal elörébb tolva a dallamcsúcsot). Ugye azért eljönne? (Kétszer, először eső, utána eső-emelkedő dallammal). De azért eljönnek? (Kétszer, először emelkedő-eső, majd eső-emelkedő dallammal). Na vajon megjött-e Mártika? (Háromszor, először emelkedő-eső, utána eső, majd eső-emelkedő dallammal).

Az első blokk kérdései (az első két kérdés és variánsai) a dallamcsúcs helyzetét hivatottak vizsgálni az általános eldöntendő kérdésekben. A második blokk mondatai (az utolsó három mondat és változatai) azt a célt szolgálták, hogy megvizsgáljuk, ezen partikulák esetén melyik dallamvariáns a domináns és természetes a hallgatók számára. 
A percepciós teszt 30 kitöltője mind magyar anyanyelvü (7 férfi és 23 nő), átlagos életkoruk 34,8 év, a legfiatalabbikuk 20, a legidősebb 67 éves (a szórás mértéke 12,08 ) volt. A kísérletben részt vevők a mondatok meghallgatása közben egy online kérdőívet töltöttek ki, amely úgy volt összeállítva, hogy a, a hasonló tartalmú megnyilatkozások a lehető legtávolabb kerültek egymástól. A tesztben három kérdésre válaszoltak mind a 14 mondattal kapcsolatban egyenként: mi a mondat modalitása (kérdés vagy állítás, választható opció volt a ,nem tudom” is); természetes-e a mondat dallama (osztályozni kellett 1-től 5-ig, ahol 5 a legtermészetesebb), és hordoz-e a semleges jelentésen túl többletjelentést (ezt röviden írásban kellett kifejteni). A kérdőívekben adott válaszok alapján kapott legfontosabb eredményeket a következő rész tárgyalja.

\section{Eredmények}

Az alábbiakban a percepciós teszt összesített eredményei következnek. A mondatok esetén nyilakkal jelöltem a főbb dallammozgások helyét és irányát, vastaggal szedve az utolsó dallamcsúcsokat képező szótagokat. A modalitás megítélésekor a 30 före vetített válaszok százalékos arányát adtam meg. A dallam természetességének megítélésekor a kapott értékek (1-től 5-ig, 5 a legtermészetesebb) átlagát tüntettem fel, a jelentésoszlopba pedig azok az extra többletjelentések kerültek, amelyeket a kitöltők az adott mondat esetén legtöbbet említettek (itt is a százalékok a 30 före vetített arányt ábrázolják).

2. táblázat. A percepciós vizsgálat eredményei

\begin{tabular}{|c|c|c|c|c|c|}
\hline \multirow[t]{2}{*}{ Mondatok } & \multicolumn{3}{|c|}{ Modalitás } & \multirow{2}{*}{$\begin{array}{c}\text { Természetesség } \\
\text { (átlag) }\end{array}$} & \multirow[t]{2}{*}{ Jelentés } \\
\hline & kérdés & állítás & $?$ & & \\
\hline \multicolumn{6}{|c|}{ Dallamtípusok összevetése } \\
\hline \multicolumn{6}{|c|}{ Dallamcsúcsok helyzetének összevetése } \\
\hline 1. És Péterék eljönnek va $\nearrow$ sár \nap? & $100 \%$ & $0 \%$ & $0 \%$ & 3,93 & remény $(17 \%)$ \\
\hline 2. És Péterék eljönnek $>\mathbf{v a} \searrow$ sárnap? & $100 \%$ & $0 \%$ & $0 \%$ & 2,97 & $\begin{array}{l}\text { remény/ } \\
\text { érdeklődés } \\
(10 \%)\end{array}$ \\
\hline 3. És Péterék eljön $\nearrow$ nek】 vasárnap? & $100 \%$ & $0 \%$ & $0 \%$ & 3,13 & remény $(13 \%)$ \\
\hline 4. Meglepte $\nearrow \mathbf{a} \searrow$ kép? & $100 \%$ & $0 \%$ & $0 \%$ & 4,37 & $\begin{array}{l}\text { érdeklődés } \\
(23 \%)\end{array}$ \\
\hline 5. Meglep $\nearrow$ te \a kép? & $93 \%$ & $0 \%$ & $6 \%$ & 4,2 & $\begin{array}{l}\text { érdeklődés } \\
(13 \%)\end{array}$ \\
\hline 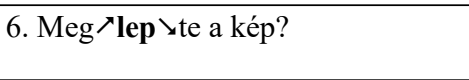 & $83 \%$ & $0 \%$ & $17 \%$ & 3,37 & $\begin{array}{l}\text { érdeklődés } \\
(23 \%)\end{array}$ \\
\hline 7. Meg \lepte a kép? & $43 \%$ & $37 \%$ & $20 \%$ & 2,73 & harag $(13 \%)$ \\
\hline 8. Ugye azért \eljönne? & $97 \%$ & $3 \%$ & $0 \%$ & 4,27 & remény $(77 \%)$ \\
\hline
\end{tabular}




\begin{tabular}{|c|c|c|c|c|c|}
\hline \multirow[t]{2}{*}{ Mondatok } & \multicolumn{3}{|c|}{ Modalitás } & \multirow{2}{*}{$\begin{array}{c}\text { Természetesség } \\
\text { (átlag) }\end{array}$} & \multirow[t]{2}{*}{ Jelentés } \\
\hline & kérdés & állítás & $?$ & & \\
\hline \multicolumn{6}{|c|}{ Dallamtípusok összevetése } \\
\hline \multicolumn{6}{|c|}{ Dallamcsúcsok helyzetének összevetése } \\
\hline 9. Ugye azért $\nearrow$ el\jön $\nearrow$ ne? & $100 \%$ & $0 \%$ & $0 \%$ & 4,47 & remény $(70 \%)$ \\
\hline 10. De azért el $\nearrow$ jön \nek? & $100 \%$ & $0 \%$ & $0 \%$ & 4,4 & remény $(43 \%)$ \\
\hline 11. \De azért eljön $\nearrow$ nek? & $40 \%$ & $40 \%$ & $20 \%$ & 3,96 & remény $(27 \%)$ \\
\hline $\begin{array}{l}\text { 12. Na vajon }>\text { megjött-e } \\
\text { Már }>\text { ti \ka? }\end{array}$ & $77 \%$ & $13 \%$ & $10 \%$ & 3,7 & gúny $(43 \%)$ \\
\hline 13. Na vajon $>\mathbf{m e g} \searrow$ jött-e Mártika? & $80 \%$ & $17 \%$ & $3 \%$ & 4,2 & gúny $(33 \%)$ \\
\hline $\begin{array}{l}\text { 14. Na vajon } \nearrow \text { meg \jött-e } \\
\text { Márti }>\text { ka? }\end{array}$ & $87 \%$ & $3 \%$ & $10 \%$ & 3,46 & gúny $(50 \%)$ \\
\hline
\end{tabular}

Az első hét példa a speciális lexikai elemet nem tartalmazó eldöntendő kérdések dallamcsúcsának helyét vizsgálja. A dallamcsúcsok minden esetben az előző szótaghoz képest érzékelhetö, 10-20\% közötti emelkedést mutatnak.

Az 1-3. megnyilatkozás (És Péterék eljönnek vasárnap?) három lehetséges dallamcsúcsot vizsgál: az utolsó előtti szótagon (1.), a megnyilatkozás végétől számított 3. szótagon (2.) és a megnyilatkozás végétől számított 4. szótagon (3.). A kitöltők mindhárom esetben egyértelmúen kérdésnek érzékelték a megnyilatkozást, az elöretolt dallamcsúcsokat tartalmazó variánsokat azonban kevésbé tartották természetesnek (legkevésbé az eggyel előretolt dallamcsúcsú változatot). Viszonylag kevés esetben véltek felfedezni jelentéstöbbletet, leginkább a reménykedést tartották valószínünek.

A 4-7. példák (Meglepte a kép?) szintén a dallamcsúcs helyét vizsgálták. Itt már nemcsak az utolsó előtti szótaghoz képest egy és két szótaggal elörébb tolt változat szerepelt, hanem egy három szótaggal előrébb tolt variáns is, amelyben ezáltal a megnyilatkozás kezdő szótagja maga esett egybe a dallamcsúccsal. A beszélők a dallamcsúcs elöretolásával párhuzamosan egyre kisebb mértékben értelmezték kérdésnek a megnyilatkozást, és ugyanebben a mértékben csökkent a természetesség ítélete is. Elsősorban érdeklődést, a mondat elejére tolt dallamcsúcs esetében pedig leginkább haragot társítottak a hallott mondathoz.

A második blokk a különböző lexikai elemeket tartalmazó (ugye, de, azért, vajon, -e) kérdések dallamát vizsgálja, több lehetséges variánst szembeállítva.

A 8-9. mondatpár (Ugye azért eljönne?) esetén a kérdés az, hogy a két megnyilatkozás közt van-e érzékelhető különbség akkor, ha az ugye kezdetű kérdő mondat eső dallammal áll (8.) vagy mondatvégi emelkedéssel (9.), amelyben az emelkedés mértéke $20 \%$. A kitöltők mindkét változat esetében hasonlóan alapvetően kérdésnek tekintették a megnyilatkozást, az eső dallam valamivel természetesebb megítélést kapott. Mindkét esetben a legtöbbször reménykedőnek tartották a megnyilatkozást, tehát a dallam iránya döntően nem befolyásolta percepciójukat. 
A 10-11. mondatpár (De azért eljönnek?) vizsgálatakor az emelkedő-eső dallam (10.) állt szemben a végén enyhe emelkedést (20\%) mutató dallammal (11.). A kérdés modalitásának tekintetében látható, hogy az emelkedő-eső variánst mindenki kérdésnek értelmezte, míg nagy a bizonytalanság a végén emelkedő változat esetében. Ez utóbbit sokkal kevésbé is tartották természetesnek. Mindkét esetben a reménykedés dominál, mint jelentéstöbblet, de inkább az emelkedö-eső mondatra tartották ezt jellemzőnek a kísérlet résztvevői.

A 12-14. mondathármas (Na vajon megjött-e Mártika?) emelkedő-eső, eső és eső-emelkedő dallamokat kontrasztál a mintában. A hallgatók jellemzően mindhárom esetben kérdésnek tekintették a megnyilatkozást, a legtermészetesebbnek az eső variáns hatott, ezt követte az emelkedö-eső, míg a legkevésbé természetes a végén emelkedő dallam. A kitöltők mindhárom esetben gúnyosnak találták a megnyilatkozást, ezt legtöbben a végén emelkedő dallam esetén látták így.

Összegzésképp, a percepciós teszt értékelésekor a következőket tapasztaljuk:

(1) Az általános eldöntendő kérdésekben a dallamcsúcs pozíciója legtermészetesebben az utolsó előtti szótag, és minél elörébb kerül ehhez képest, annál kevésbé hat természetesnek a mondat. A nagymértékben elöre tolt (hátulról a 4. szótag) dallamcsúcs esetén a megnyilatkozás már nem is egyértelmüen kérdés a beszélők számára.

(2) A bizonyos lexikális partikulát tartalmazó eldöntendő kérdések esetében (de, ugye, azért, vajon, -e) a beszélők természetesebbnek ítélik meg az eső dallamokat, a legkevésbé természetesnek a végén emelkedő dallamokat tekintik. Az emelkedő végü változatok esetén nem volt a többi dallamváltozathoz képest biztosan elkülöníthető jelentéstartalom. A de azért szókapcsolat esetén a megnyilatkozás kérdés státusza is megkérdőjelezhető az adatközlők szerint, amennyiben a dallam esö-emelkedő.

\section{Következtetések és összegzés}

A tanulmány azt elemezte, hol helyezkedhet el a dallamcsúcs, illetve milyen körülmények között valósulhat meg emelkedő végü intonációs dallam a magyar eldöntendő kérdésekben. Áttekintettem az általános eldöntendő kérdések kontúrvariánsait, az utolsó elötti szótagban határozva meg alapértelmezetten a dallamcsúcsot. Az emelkedő végü dallamok esetén olyan kontúrok jelentkezését vizsgáltam, amelyek a kérdés legalább utolsó előtti szótagjától töretlen emelkedést mutatnak. Amint látható volt, csak összetett (emelkedő-eső, illetve eső-emelkedő) dallamok jellemzők azokra a magyar eldöntendő kérdésekre, amelyekben végső emelkedés szerepel.

Az általános eldöntendő kérdések normatív esetben emelkedő-eső kontúrt kapnak, ahol az emelkedés különböző típusai a mondat utolsó föhangsúlyától indulnak, és az utolsó elötti szótagig tartanak, ahonnan egy radikális esés tapasztalható. Az egyik eset, amelyben az általános eldöntendő kérdések végső emelkedést mutatnak az, amikor legfeljebb két szótagból állnak, mert a tipikusan jellemző emelkedő-eső dallam csak 
három és több szótagú kérdéseken tud a maga teljességében megvalósulni. A másik eset az, amikor az eldöntendő kérdés a mondat utolsó szaván is főhangsúlyos, tehát onnan indul az emelkedő-eső dallam, és ez a szó maximálisan két szótagú. Meg kell említeni azonban, hogy ez a végső emelkedés csak fonetikai megnyilvánulása egy fonológiailag emelkedö-eső dallamnak. Fontos kiemelni, hogy az emfatikus, ismételtető eldöntendő kérdések, amelyek gyakran fejeznek ki hitetlenkedést a kérdező részéről, már egy szótag esetében is az emelkedő-eső dallamot használják, így ott nem számíthatunk emelkedő végü dallamra.

Az eddig tárgyalt emelkedő dallamok csupán az emelkedő-eső dallam szótagszámfüggő fonetikai variánsai voltak. Meg kell azonban említenünk azokat a lexikai elemektől függő eseteket is, ahol szótagszámtól függetlenül fonológiailag is emelkedő dallam kíséri az eldöntendő kérdést. Azokban a mondatokban, amelyek jellemzően egy negatív vagy ellentétes értelmü lexikai elemet tartalmaznak, használható az alapértelmezett emelkedő-eső dallamon kívül az eső-emelkedő is: ezekben az esetekben a kérdés reménykedő vagy fenyegető felhangot kap, ez utóbbi esetben a kérdés a felszólítás irányába tolódik el. Fontos, hogy az eső-emelkedő dallam eldöntendő kérdő jelleggel csak ezeknek a lexikai elemeknek a jelenlétében használható. A csak nem szókapcsolatot tartalmazó eldöntendő kérdések viszont kizárólag eső-emelkedő dallammal állnak, mert a mondat jelentése már e két elem által meghatározódik, csak meglepődést, reménykedést kifejező kérdés lehet, általános (nem jelölt) eldöntendő kérdés nem.

Ami a végső soron mégis emelkedő végü dallammal szereplő eldöntendő kérdések jellemzőit illeti, ez az emelkedés egy viszonylag enyhe, maximum 40\%-ot mutat, és kizárólag az utolsó előtti szótagról indulhat. Az eldöntendő kérdésekben tehát nem léteznek az utolsó hangsúlyos szótagról induló, egykomponensủ emelkedő dallamok.

A tanulmány második felében 30 magyar ajkú adatközlő bevonásával egy percepciós teszt segítségével azt vizsgáltam, (1) mennyire fogadható el, ha az általános eldöntendő kérdések esetében az utolsó előtti szótagról a dallamcsúcsot előrébb toljuk; (2) mennyire tekinthető természetesnek és milyen jelentéstöbblettel bír bizonyos partikulákkal álló (ugye, de azért, vajon, -e) eldöntendő kérdések esetében, ha dallamuk emelkedő végü.

Az eredmények alapján elmondható, hogy az általános eldöntendő mondatok dallamcsúcsa legtermészetesebb pozícióban az utolsó előtti szótagon realizálódik. Ehhez képest egy vagy két szótaggal előre tolva a mondat veszít természetességéből, de továbbra is kérdésként értelmezhető. Hátulról a negyedik szótagra tolva azonban már bizonytalan a kérdésstátusz, és jóval kevésbé hat természetesnek is. Az emelkedő végü dallamok kevésbé természetesek a beszélők számára, amennyiben ezekkel a partikulákkal álló eldöntendő mondatokat kísérnek. Egyértelmüen ehhez a dallamváltozathoz köthetó jelentéstöbbletet az adatokból nem sikerült kimutatni.

A jövőben érdemes halandzsaszöveggel és nem értelmes mondatokkal is elvégezni a vizsgálatot, különösen a partikulás kérdések esetében, hiszen az ugye vagy a vajon, -e szavak eleve sugallják a mondat kérdésként történő értelmezését. A kutatás eredményei a magyar mint idegen nyelv oktatásában is felhasználhatók, különös tekintettel a beszédszintézisen alapuló digitális nyelvtanítási módszerekre. 


\section{SZAKIRODALOM}

Baditzné Pálvölgyi Kata 2012. Spanish Intonation of Hungarian Learners of Spanish: Yes-or-no Questions. Eötvös Loránd Tudományegyetem, Budapest.

Boersma, Paul - Weenink, David 2020. Praat: doing phonetics by computer [Computer program]. Version 6.1.16, https://www.fon.hum.uva.nl/praat/.

Cantero, Serena - Francisco, José 2002. Teoría y análisis de la entonación. Universitat de Barcelona, Barcelona.

Cantero, Serena - Francisco, José 2005. Patrones melódicos del español en habla espontánea. Universitat de Barcelona, Barcelona.

Cantero, Serena - Francisco, José - Font Rotchés, Dolors 2007. Entonación del español peninsular en habla espontánea: patrones melódicos y márgenes de dispersión. Moenia 13: 69-92.

Cantero Serena - Francisco, José - Font Rotchés, Dolors 2009. Protocolo para el análisis melódico del habla. Estudios de Fonética Experimental XVIII: 17-32.

Cantero, Serena - Francisco, José - Font-Rotchés, Dolors 2020. Melodic Analysis of Speech (MAS). Phonetics of Intonation. In: Abasolo, Juan - de Pablo, Irati - Ensunza, Ariane (eds).: Contributions on education. Universidad del País Vasco, Bilbao, 20-47.

Csüry Bálint 1925. A szamosháti nyelvjárás hanglejtésformái. A Magyar Nyelvtudományi Társaság Közleményei 22. Budapest.

Csüry Bálint 1928. Egressy a „kedély magyar accentusá”-ról. Magyar Nyelv 24: 42-4.

Font Rotchés, Dolors 2006. Corpus oral de parla espontània. Gràfics $i$ arxius de veu. Biblioteca Phonica 4. http://www.ub.edu/lfa.

Font-Rotchés, Dolors 2007. L'entonació del català, Biblioteca Milà i Fontanals 53. Publicacions de l'Abadia de Montserrat, Barcelona.

Font-Rotchés, Dolors 2008. Els patrons entonatius de les interrogatives absolutes del català central, Llengua i Literatura 19: 299-329.

Font-Rotchés, Dolors 2009. Les interrogatives pronominals del català central. Anàlisi melòdica i patrons entonatius. Els Marges. Revista de llengua i literatura 87: 41-64.

Markó Alexandra 2007. Kérdő funkciójú hanglejtésformák a spontán beszédben. Beszédkutatás 2007: 59-74.

Varga László 1981. A magyar intonáció-funkcionális szempontból. Nyelvtudományi Közlemények 83: 313-39.

Varga László 2002a. Intonation and Stress: Evidence from Hungarian. Palgrave Macmillan, Houndmills, Basingstoke.

Varga László 2002b. The Intonation of monosyllabic Hungarian Yes-No questions. Acta Linguistica Hungarica 49: 307-20. https://doi.org/10.1556/ALing.49.2002.3-4.4

Varga László 2009. A magyar „hullámzatos hanglejtésforma”, és amit a hangsúlyról elárul. In: É. Kiss Katalin - Hegedűs Attila (szerk.): Nyelvelmélet és dialektológia. PPKE, Piliscsaba, 31-46.

\section{Baditzné Pálvölgyi Kata egyetemi adjunktus}

Eötvös Loránd Tudományegyetem https://orcid.org/0000-0002-7106-7427 


\section{SUMMARY}

\section{Baditzné Pálvölgyi, Kata}

\section{Melodic peak displacement and end-rising contours in Hungarian yes-no questions}

This study investigates two aspects of Hungarian intonation: the presence of melodic peaks in general yes-no questions and the issue of under what circumstances yes-no questions can end with a rising final inflection. The normative realization of standard yes-no questions in this language is characterised by an end-falling contour, a rise-fall. The intonation of this contour involves a rise or a plateau (or a combination of the two) from the last main-accented syllable to the penultimate syllable, from where the melody falls. Still, in short, maximally disyllabic yes-no questions or emphatic yes-no questions with the last main accent stretching over up to two syllables, the rise-fall is realised phonetically only as a moderate rise. There are certain lexical items, however, the presence of which makes it possible to apply a falling-rising contour besides the standard rising-falling one. These yes-no questions imply divergence from the unmarked meaning, and an ultimately rising melody at the end of the question.

According to a perception test administered to 30 Hungarian informants, the melodic peak of general yes-no questions can be displaced to the antepenultimate syllable or even to the one before that, without changing the interpretation of the utterance as a question by listeners - but the most natural position is still the penult. Yes-no questions including a special question particle can effectively be accompanied by a falling-rising melody, but listeners find its presence less natural than end-falling contours in those utterances.

Keywords: yes-no interrogatives, rising final inflection, peak, fall-rise, rise-fall 